in the altered direction of the cilia, no traces of operative interference remain. A Snellen's clamp is applied to the lid, care being taken, before the screw is tightened, to stretch the skin upwards, and so tilt the margin of the lid forwards. With a Beer's knife the tarsal cartilage is split along the whole length of its free edge, up to a distance of two milli. metres from the puncture, and to a depth of about four millimetres. An incision is made through the skin and connective tissue of the lid, parallel with the row of cilia, from three to four millimetres above it. The surface of cartilage exposed is cleared from connective tissue and an incision is made into it, through about a third of its thick ness, parallel with the lower edge of the skin wound and from two to three millimetres above it. The point of the knife is inserted through the first wound in the edge of the cartilage, and brought out at the middle of the second incision in it, above the cilia. Carrying the knife in the same plane, the incisions are connected in their whole length. Thus the row of cilia and a piece of the tarsal cartilage are separated from the lid except at each end. A section of the separated tissue would appear wedge-shaped, the edge of the wedge upwards. The wedge of tissue is then rotated so that the edge of it points downwards and inwards, and is in contact with the eyeball, while the row of cilia points outwards and upwards. The skin wound is united with three or four fine sutures, the clamp removed, and an ordinary dressing applied. The sutures should be removed about the third day. The measurements mentioned are only approximate, and must vary with the thickness and size of the lid to be operated on.

I have ventured to describe this as a new operation. I apply the epithet "new" with a certain amount of diffidence. Whether it be so or not the central idea of it-namely, the rotation of the wedge-shaped bridge of tissue and the complete alteration in the direction of the cilia which it effects-is the outeome of my observation of and practice on many a score of cases of entropion during the last ten years.

Sydney, N.S.W.

THE GARIEL AIR-BALL PESSARY AS I PLUG IN ABORTION

By J. Chalmers Roberison, M.B., C.Mr.

I wISH to call the attention of practitioners to the use of the Gariel air-ball pessary as a plug in early abortion. The idea is not original. I saw it casually mentioned some years ago in one of the medical papers, but, as far as I can ascertain, few are aware of the advantages of this instrument. In those cases where the orum is not completely detached, and is, moreover, out of reach, and hremorrhage more or less alarming is going on, the best results follow the use of the air-ball pessary. The ordinary process of plugging by pledgets of wool or by prepared tampons is laborious and precious time is lost. On the other hand, one can introduce the air-ball pessary and inflate it in half a minute; the upper vagina is most effectually plugged, and the patient can be left with safety for a couple of hours or more. The presence of the pessary is a powerful excitant of uterine action, and one usually finds at the next visit the ovum detached and lying on the top of the pessary. I have used this instrument on several occasions, and always carry one in my obstetric bag. Before insertion it is well washed with a solution of corrosive sublimate, and then smeared with an antiseptic lubricant.

Wandswortl-common, s.W.

STRANGULATED INGUINAL HERYIA COMPLICATED WITH DOUBLE HYDROCELE AND RETENTION OF URINE.

BY G. BELBEX FlUX, M.D.

ONE day in November of last year I was called at 3 P.M. to see a man aged seventy-two, who could not pass his urine. On arrival, I found the patient in bed, with stercoraceous romiting and very collapsed. His bladder was distended nearly to the umbilicus, the scrotum was enormously enlarged, and the penis was to be observed as a mere dimple. The fluid in the scrotum extended right up to the external abdominal rings. There was no impulse on coughing, and the distended scrotum was dull and translucent. The right cord was obscured, but appeared to be thickened.

The urine was drawn off with a flexible silk catheter without difficulty. Then with a small trocar I removed about a pint and a half of Huid from the left hydrocele. The right side still being translucent and dull, and giving a sensation of fluctuation to the touch, it was also punctured and about a pint of clear straw-coloured fluid withdrawn. The fluid being removed from both hydroceles, I found on the right side an inguinal hernia, evidently strangulated. Taxis for a few minutes failed to reduce the bowel, and was then given up temporarily; the patient vomited less during the night and slept for some hours. In the morning taxis was again tried and was at once successful, and the vomiting ceased entirely. Three days later, during violent coughing, the hernia again descended and became strangulated, well-marked stercoraceous vomiting again coming on. Chloroform was administered and the bowel was returned at once. The vomiting ceased immediately, and the patient improved rapidly. A suitable truss having been obtained, the patient recovered, and was able to resume his ordinary work as an agricultural labourer.

Highwortl.

\section{9 算tintror}

\section{HOSPITAL PRACTICE, BRITISH AND FOREIGN.}

Nulla autem est alia pro certo noscendi via, nisi quamplurimas et morbortu et dissectionum historias, tim aliorum tum proprias collectas habere, et inter se comparare.-MoRGAGNI De Sed. et Caus. Morb., lib. iv. Procemium.

\section{THE LONDON HOSPITAL.}

A CASE OF TETANY IN PREGNAXCY, WITH NEPHRITIS AND CANCER OF THE PYLORUS ; REMARKS.

(Under the care of Dr. Herman.)

THere are many points of interest in this case, which we give at some length. The occurrence of tetany as a complication of pregnancy is unusual. With regard to the influence of nephritis in the mother on the life of the child, Cohn ${ }^{1}$ estimates the mortality as 87 per cent., due to endarteritis of the placenta, with death of the connective tissue. For the report of the case we are indebted to Dr. Hugh Smith, resident accoucheur, and Messrs. A. Bullied and A. Halliday Smith, clinical clerks.

J. M. J__, aged thirty, first menstruated when fourteen years old ; has always been regular; quantity moderate ; no pain. Was married at eighteen; six children, two miscarriages; last confinement a year and ten months ago. Morning sickness in each pregnancy, but in no previous one beyond the third month. Labours easy; free hæmorrhage afterwards. Suckled each child fourteen months. Never had any kind of fit. Expected to be confined at the end of January. During this pregnancy she suffered from vomiting, not limited to the morning, often eight or nine times in the twenty-four hours. During the last four or five months there have been loss of appetite, constipation, and wasting; and she has had cramps in the calf of the left leg. In other respects she was well until Dec. 9th. She then noticed in the morning that the thumbs were drawn into the palms of the hands, and the fingers were stiff. The hands felt numb and tingled, and she was unable to use them. The wrists were bent, and the hands fixed with the palms downwards. Both hands were affected alike. After about an hour the hands became less stiff, but on attempting to use them the spasms recurred. During the spasms of the upper extremities there was some stiffness and numbness of the feet, but only momentary inability to move them. There was some stiffness at the back of the neck, which was slightly drawn back, and the back and sides of the head were numb. Similar spasms recurred throughout Dec. 10th, 11th, and 12th; more persistent on the latter day, and about 4 P.M. she was admitted.

On admission, both hands and forearms were in tonic spasm. Elbows flexed, but flexors in upper arm not rigid. 